Diabetologia 7, $168-172(1971)$

(c) by Springer-Verlag 1971

\title{
Asymptomatic Neurogenic Bladder in Juvenile Diabetics
}

\author{
I. Famrman, M. Maler, M. Jadzinsky, E. Alvarez, D. Fox, J. Zilbervarg, J.B. Cibeira and R. Colinas \\ Departments of Nutrition, Urology and Radiology of Hospital Carlos Durand, Buenos Aires and Center of \\ Rehabilitation of the Cripple, Argentina
}

Received: July 8, 1970, accepted: February 15, 1971

Summary. The present report concerns investigation of bladder disturbances in 31 juvenile diabetics. It was shown that: 1 . The predominant lesion is one of neuropathy. - 2. Vesical involvement such as increased capacity and atony was demonstrated by cystometry in 27 out of the 31 cases $(87 \%)$. - 3. 4 cases had neck hyper trophy. - 4. The most striking symptom was a large volume of first morning urine. This information was elicited from the patients. They had no urological complaints. - 5. A high incidence of impotence was seen in diabetics with neurogenic bladder. - 6. The possible causes of such lesions and the value of certain therapeutic measures was discussed. jeunes

Vessie neurogène asymptomatique chez des diabétiques

Résumé. Le présent travail concerne une investigation sur les troubles de la vessie chez 31 diabétiques jeunes. II a été démontré que: 1. La lésion prédominante est une Iésion de neuropathie. - 2. Des signes vésicaux tels que la capacité accrue et l'atonie mesurées par cystométrie ont été démontrés dans 27 cas sur les 31 (87\%). - 3. 4 cas avaient une hypertrophie du col. - 4. Le symptome le plus frappant était l'important volume de la première urine du matin. Ceci a été indiqué par les patients. Ils ne se plaignaient d'aucun trouble urologique. -5 . On trouve une haute fréquence d'impuissance chez les diabétiques ayant une vessie neurogène. - 6. Les causes possibles de telles lésions et la valeur de certaines mesures thérapeutiques sont discutées.

Asymptomatische neurogene Blasenstörung bei jugendlichen Diabetikern

Zusammenfassung. Es wird über Blasenstörungen bei 31 jugendlichen Diabetikern berichtet. Es konnte gezeigt werden, daß: 1, die Neuropathie die vorherrschende Störung darstellt; 2 . bei 27 von 31 Fällen (87\%) eine Blasenbeteiligung (gesteigerte Kapazität und zytometrisch nachweisbare Atonie) vorlag; - 3. bei 4 Fällen eine Blasenhalshypertrophie bestand; - 4. hervorstechendes Symp. tom war die große Harnmenge bei der ersten morgendlichen Blasenentleerung, über das die Patienten auf Anfrage berichteten. Sie äußerten keine urologischen Beschwerden; - 5. Bei vielen Diabetikern mit einer neurogenen Blasenstörung ist eine Impotenz festzustellen; 6. Die für diese Läsionen in Frage kommenden Ursachen und der Wert einiger therapeutischer Maßnahmen werden diskutiert.

Key-words. Neurogenic bladder, juvenile diabetes, cystometry, impotence, neuropathy, intravesical pressures, vesical capacity, bioelectric test, residue urinary, first matinal micturition.
The bladder lesion due to diabetic neuropathy, was first pointed out by Marchal de Calvi in 1864 [26]. Since then many authors have presented isolated cases $[1,4,39]$. These studies were done on patients with urological symptomalogy and specific vesical studies were included in the work-up $[4,39]$. It is only lately that a systematic search has been made for the resical lesion in patients with no previous clinical disturbances $[13,17,12,26]$.

This problem has not been specifically studied in juvenile diabetics. In this type of diabetes, the renal lesion is the most frequent cause of death [27]. Although the disturbance is produced by glomerular vasculopathy (glomerulosclerosis of Kimmelstiel and Wilson), any additional pathogenic factor, such as infection, will be another element contributing its share to the renal lesion.

We believe that the state of the bladder should be studied routinely in diabetics in general and in juveniles in particular. Bladder pathology and its influence upon renal function is being studied by our team and will be the subject of our next report.

Taking into account that the non-myelinated fibres are the earliest and most strongly damaged in diabetes and that the detrussor muscle is innervated by this type of fibre, the exploration technique to be used deals with the manifestations at the vesical level of the possible engagement of its nervous pathways. It is an accepted fact that the absence of voiding desire indicates that the afferent pathway from bladder to the medullary centres is blocked or interrupted [21].

\section{Material and Methods}

31 diabetic patients of the infant-juvenile type (WHO classification) [38] have been studied: 24 males and 7 females, their ages ranging from 14 to 46 years. The average age in the series was 24 years 4 months. In 17 patients the diabetes began before age $14 ; 14$ of the patients were diagnosed between the ages of 14 and 24. The 
average duration of diabetes was over 9 years, ranging from one month to 27 years. All patients were insulin dependent (see Table 1 and 2).

The clinical examinations included:

1. complete physical examination, funduscopy, oscillometry, electrocardiography, and special emphasis on bio-electrical and clinical neurologic tests.

2. urologic study: complete clinical examination, discarding patients with prostatic hypertrophy or urethral stricture; meticulous history of micturition. Cystometry scope. Retrogradecystographies were made using a sodium iodide solution $(12 \%)$ until imminent desire was provoked. Radiocinematography was done in 3 cases.

3. Bio-electrical study was performed on 24 patients. The electronic records were obtained with an electromyograph and DISA stimulator.

The former operates on 3 channels with a frequency ranging from 3000 to 10000 cycles per second. Continuous and interrupted records and the velocity of motor nerve conduction were obtained by means of photographic registers with a film speed ranging from 5 to $100 \mathrm{~cm}$ per

Table 1. Clinical characteristics

\begin{tabular}{|c|c|c|c|c|c|c|c|c|c|c|c|}
\hline No. & Name & Sex & Age & $\begin{array}{l}\text { Duration } \\
\text { of dia- } \\
\text { betes } \\
\text { (Years) }\end{array}$ & $\begin{array}{l}\text { Insulin- } \\
\text { treat- } \\
\text { ment }\end{array}$ & $\begin{array}{l}\text { Nephro- } \\
\text { pathy }\end{array}$ & $\begin{array}{l}\text { Neuro- } \\
\text { pathy }\end{array}$ & $\begin{array}{l}\text { Retino- } \\
\text { pathy }\end{array}$ & $\begin{array}{l}\text { Tmpo- } \\
\text { tence }\end{array}$ & $\begin{array}{l}\text { Vesical } \\
\text { capacity }\end{array}$ & $\begin{array}{l}\text { Resid- } \\
\text { ual }\end{array}$ \\
\hline 1 & V.V. & M & 20 & 7 & + & + & + & + & + & $1000(\mathrm{ml})$ & 0 \\
\hline 2 & G.M. & $\mathbf{M}$ & 33 & 10 & + & - & + & + & + & 430 & 0 \\
\hline 3 & H.M. & M & 27 & 12 & + & + & + & + & + & 1000 & 180 \\
\hline 4 & O.P. & $\mathbf{M}$ & 38 & 15 & + & - & + & + & + & 700 & 0 \\
\hline 5 & M.I. & F & 18 & 13 & + & + & + & - & & 900 & 75 \\
\hline 6 & M.T. & $\mathrm{M}$ & 40 & 17 & + & + & + & + & + & 750 & 0 \\
\hline 7 & A.F. & $\mathbf{M}$ & 20 & 1 & + & - & - & - & - & 750 & 0 \\
\hline 8 & F.D. & $\mathbf{F}$ & 36 & 20 & + & - & - & - & & 550 & 0 \\
\hline 9 & C.C. & M & 28 & 23 & + & + & + & + & + & 630 & 0 \\
\hline 10 & C.A. & $\mathrm{M}$ & 18 & 1 & + & - & + & $\frac{1}{-}$ & - & 1000 & 0 \\
\hline 11 & M.S. & $\mathrm{F}$ & 22 & 11 & + & + & & + & & 1000 & 0 \\
\hline 12 & R.V. & $\mathrm{M}$ & 14 & 1 & + & - & - & - & - & 550 & 0 \\
\hline 13 & H.P. & $\mathbf{F}$ & 16 & 4 & + & - & 一 & - & & 720 & 0 \\
\hline 14 & I.T. & $\mathbf{M}$ & 38 & 24 & + & + & + & + & + & 470 & 0 \\
\hline 15 & R.S. & $\mathbf{F}$ & 33 & 27 & + & + & - & + & & 1000 & 0 \\
\hline 16 & V.R. & $\mathrm{M}$ & 18 & 5 & + & - & - & - & - & 700 & 50 \\
\hline 17 & J.B. & M & 17 & 4 & + & - & - & - & - & 570 & 0 \\
\hline 18 & A.A. & $\mathbf{F}$ & 19 & 1 & + & - & - & - & & 800 & 0 \\
\hline 19 & M.L. & M & 27 & 14 & + & + & + & + & + & 750 & 0 \\
\hline 20 & H.O. & $\mathrm{M}$ & 16 & 2 & + & 二 & - & - & - & 950 & 0 \\
\hline 21 & L.C. & $\mathbf{F}$ & 22 & 1 & + & 一 & - & - & & 500 & 0 \\
\hline 22 & J.C. & M & 24 & 4 & + & - & - & - & - & 700 & 0 \\
\hline 23 & L.G. & $M$ & 16 & 6 & + & - & + & - & - & 800 & 0 \\
\hline 24 & F.P. & M & 19 & 6 & + & - & - & - & - & 1000 & 0 \\
\hline 25 & J.C. & M & 21 & 11 & + & - & - & + & - & 850 & 0 \\
\hline 26 & H.G. & $\mathbf{M}$ & 31 & 7 & + & - & + & - & + & 700 & 0 \\
\hline 27 & J.O. & $M$ & 20 & 8 & + & - & - & - & - & 450 & 0 \\
\hline 28 & A.L. & $\mathbf{M}$ & 25 & 1 & + & - & - & - & - & 800 & 70 \\
\hline 29 & A.F. & $\mathbf{M}$ & 25 & 1 & + & - & - & - & - & 500 & 0 \\
\hline 30 & F.E. & $\mathbf{M}$ & 45 & 24 & + & - & - & + & - & 900 & 70 \\
\hline 31 & M.P. & $\mathbf{M}$ & 17 & 6 & + & - & - & - & - & 800 & 0 \\
\hline
\end{tabular}

Table 2. Classification according to duration of diabetes

\begin{tabular}{llll}
\hline 0 to 1 year & 1 to 5 years & 5 to 10 years & over 10 years \\
\hline 7 & 5 & 7 & 12 \\
\hline
\end{tabular}

with catheter Bequille C-16-18, conected to a water cystotonometer, using $0.9 \% \mathrm{NaCl}$ (the records were taken at the level of the pubis of the patients, checking and recording the pressure every $100 \mathrm{ml}$ ). Thus a pressure curve for each patient was drawn. First voiding desire and the imminent sensation of micturition were determined. Instillation of fluid was then interrupted. Vesical capacities over $500 \mathrm{ml}$ were considered pathologic. Bors Test-sensitivity of urethral mucosa to cold (instillation of ice wa. ter for $1 \mathrm{~min}$ ) was done.

After the bladder was emptied we perfomed a cysto. scopic study in doubtful cases using the Gentile Cysto- second. Disa Electrodes were used [bipolar coaxials of the K 14, 722 type]. Electromyographic records were taken using the techniques mentioned, on: the quadriceps, anterolateral extensor digitorum of the foot, and triceps surae muscles; bilaterally and on at least 10 units of each of them.

The speed of motor nerve conduction was registered in the common peroneal with proximal stimulating areas, at the level of the fibula and distal stimulation area at the level of the ankle. Responses were recorded by means of electrodes at the muscles of the foot. The conduction speed was registered four or more times and the results averaged. Stimulation was performed using supramaximal rectangular waves with surface electrodes (distal negative pole).

A group of 8 controls (5 males, 3 females) of the same age, without diabetes and urological problems, was studied in the same way as the diabetic patients (Figure $1-2$ ). 


\section{Results and Discussion}

The results obtained in this study have demostrat. ed several facts.

First, we have noted the high percentage of patients with neurologic lesions of the bladder in juvenile diabetics (Tables 3). Larcan [26], Fagerberg [17],

Table 3. Percentage of abnormal bladders

\begin{tabular}{lcl}
\hline Abnormal bladder & 27 patients & $87 \%$ \\
\hline Normal bladder & 4 patients & $\mathbf{1 3} \%$ \\
\hline
\end{tabular}

Table 4. Urological disturbances

\begin{tabular}{lll}
\hline Residual urine & 5 patients & $16 \%$ \\
\hline Neck hypertrophy & 2 patients & $6 \%$ \\
\hline Neck esclerosis & 2 patients & $6 \%$ \\
\hline
\end{tabular}

Table 5. Relationships between vesical volume and duration of diabetes

\begin{tabular}{lllll}
\hline & $\begin{array}{l}0 \text { to } 1 \\
\text { year }\end{array}$ & $\begin{array}{l}\text { 1 to 5 } \\
\text { years }\end{array}$ & $\begin{array}{l}5 \text { to } 10 \\
\text { years }\end{array}$ & $\begin{array}{l}\text { over 10 } \\
\text { years }\end{array}$ \\
\hline Normal & 1 & 1 & 1 & 1 \\
\hline Abnormal & 6 & 4 & 6 & 11 \\
\hline pathological cases & $85 \%$ & $80 \%$ & $85 \%$ & $91 \%$ \\
\hline
\end{tabular}

Table 6. Bioelectrical test

\begin{tabular}{lrr}
\hline Normal & 5 & $21 \%$ \\
\hline Abnormal & 19 & $79 \%$ \\
\hline Totals & 24 & $100 \%$ \\
\hline
\end{tabular}

and Ellenberg [13] when considering the same problem showed an incidence of between $58 \%$ and $83 \%$. These figures overlap the ones we have found, although no special group of patients of the juvenile type is presented. It is worth while mentioning here that Yamagata [40] at the Congress of the International Diabetes Federation, in 1967, pointed out that in his series diabetic neuropathy eventually affected $99 \%$ of the cases [40].

The control of diabetes and its relation to neuropathy is difficult to assess since the determination of good or bad control turns out to be very complex. This is a subject under active discussion. The complexity of the problem is very well treated in the excellent monograph of Knowles [25], by Larson [27] and in the Banting Lecture of 1967 by Marble [28, 29].

As regards the duration of diabetes, it is obvious that the longer the duration the greater is the incidence of neuropathy, and consequently also of the bladder lesion (see Table 5).

We agree with other authors in the fact that the older the lesion, the higher is the frequency and the severity $[14,15,16,31,32,33)$. The lesion seems to be independent of the degree of control of diabetes (Table 5).

None of the patients complained of urinary symptomatology. Nervertheless, careful questioning elicited

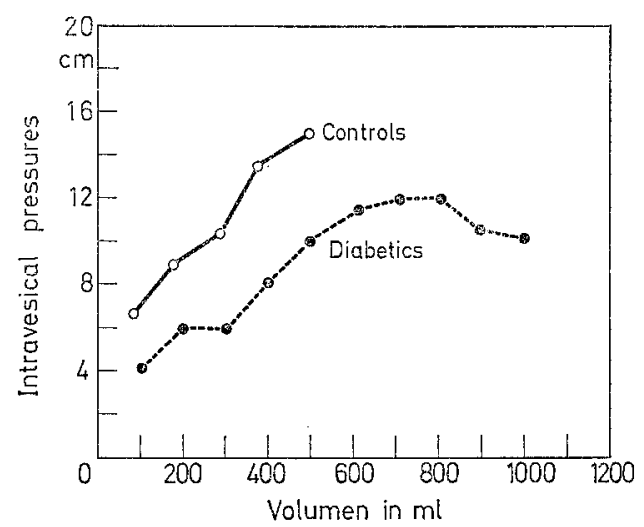

Fig. 1. Average of intravesical pressures. Control group: intravesical pressures in the normal range. Diabetics $p a-$ tients: intravesical pressures lower, in spite of greater volumes

some mention of vesical disturbances, which were later confirmed by means of instrumental study. The absence of nocturia in many cases was striking. This pleases the patient since he does not have to interrupt his sleep. It pleases the physician for the thinks his patient is metabolically compensated with little or no glycosuria. However this is not so. The first morning urine volume is frequently over $1000 \mathrm{ml}$, and in many cases $1300 \mathrm{ml}$ was found. These patients excrete urine during the night into an insensitive bladder. Hence no nocturia. The first micturition in the morning should be measured by the patient as it is an interesting datum for the doctor. He would then find neurogenic bladder more frequently.

Owing to detrussor atony, the patient can initiate voiding only with the help of abdominal pressure. This can be easily shown by having the patient try to void urine when in the horizontal position. We have been able to register some of the cases by means of radiocinematography [15]. It is interesting to point out that voiding desire in some patients is replaced by hypogastric heaviness, on account of the exaggerated bladder distension $[1,2,3,21,15]$.

As regards the absence of urinary symptoms in this group of patients, our series agrees with that of Ellenberg [13], Larcan [26], and Fagerberg [17] who studied all diabetics systematically to find asymptomatic vesical lesion. Our series differs from theirs in the fact that we have worked with juvenile diabetics, who are not usually suspected of having the lesion.

Another fact worthwhile pointing out is the frequent association of vesical neuropathy and sexual impotence in these patients $[22,23,24,31]$. Table 7 shows this association. It can be understood if we remember that innervation of sexual erection as well as that of micturition runs along the same nerve cords with spinal centres at $\mathrm{S} 2-\mathrm{S} 4$. 
We believe that these findings favour our thesis that sexual impotence in a diabetic is due to visceral neuropathy $[3,22,23,36]$, and not to a hormonal disturbance as some authors affirm $[34,35]$. Owing to the nearness of the spinal centres that govern these functions, and the fact that all nerve cords run along the same pathways, we suggest that vesical function should be explored in all diabetics with impotence [3, $15]$.

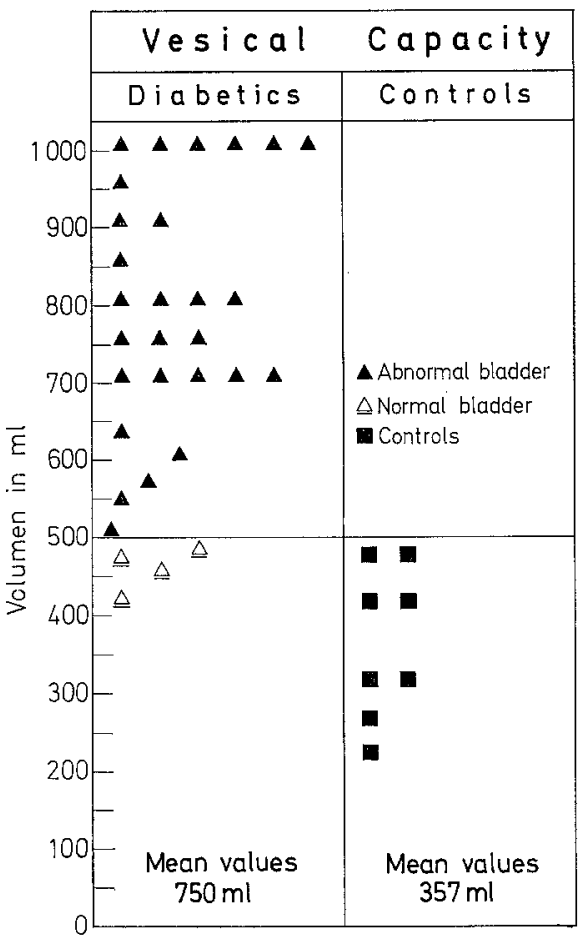

Fig. 2. Vesical capacity. 27 diabeties patients with vesical capacity above the normal values (mean $750 \mathrm{ml}$ ); 8 control cases in the normal area (mean $350 \mathrm{ml}$ )
Finally, we point out the usefulness of studying diabetic neuropathy using bio-electrical methods which measure the speed of conduction and record muscle activity $[6,7,15]$. On account of their extraordinary sensivity these methods should be systematically used to discover diabetic neuropathy and to measure the degree of illness $[19,20]$.

Patients not showing symptoms at clinical examination may already have the lesion when examined with the electrical recorder. This fact increases the number of patients with neurologic disturbances $[19$, 20]. The excellent studies of Gregersen [19] and S. Fagerberg [17] which our findings have confirmed, show

Table 7. Correlation between sexual impotence and neurogenic bladder

\begin{tabular}{lll}
\hline Neurogenic bladder & Impotence & $\%$ \\
21 & & 7 \\
\hline Impotence & Neurogenic bladder & $\%$ \\
9 & 7 & 78 \\
\hline
\end{tabular}

In the neurogenic bladder group the impotence is present in $33 \%$, while in the impotent group the neurogenic bladder is present in $78 \%$.

that neuropathy can appear very early during the course of diabetes, and may even be the first symptom to lead to a diagnosis, the patient being still ignorant of his disease (Table 6). It has been shown that motor lesions, in diabetic neuropathy, may precede the sensory lesion in the bio-electric record and the detrussor muscle may be involved in this phenomenon [19, 20]. In the series of Gregersen $[19,20], 40 \%$ of the patients examined, already had the motor lesion before completing five years of known diabetes. According to those data that author comes to the conclusion that diabetic neuropathy is initiated early and develops gradually with the duration of diabetes [20].
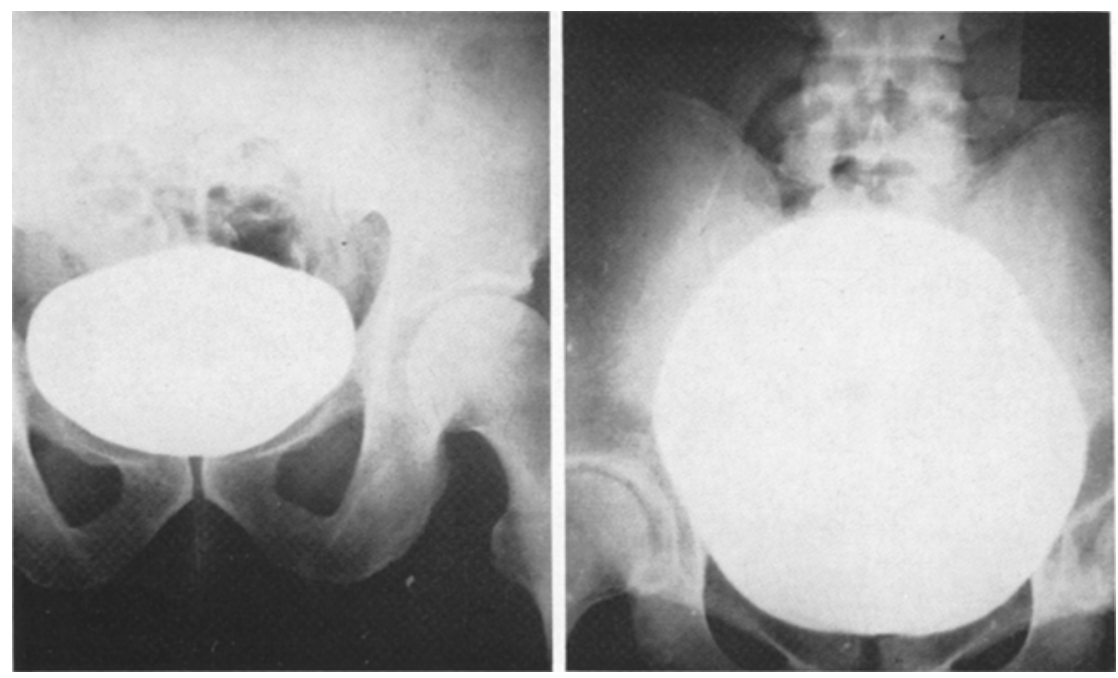

Fig. 3. Comparison between two bladders in diabetic 'patients. Left. Normal bladder 350 ml capacity. Right: Abnormal bladder $950 \mathrm{ml}$ capacity 
As far as pathogenesis and physiopathology of diabetic neuropathy is concerned, there is much literature available so that it will not treated here $[2,8,9,10,14$, $18,31,33]$.

Finally, according to our data presented here, we suggest that the vesical disturbance must be looked for in diabetics patients because of its importance and of its frequent occurrence.

\section{Therapeutic Measures}

In presence of a neurogenic bladder in a diabetic patient we suggest the following measures:

1. Obviously, a correct diabetic treatment.

2. Re-education of micturition: voiding every $3-4 \mathrm{~h}$, and helping with intrabdominal pressures.

3. Treatment of urinary disturbances such as obstacles, adenomas etc.

4. Avoiding of instrumental procedures.

5. Treatment of infections, if present.

\section{References}

1. Balfour, J., Ankenman, G.J.: Atonic neurogenic bladder as a manifestation of diabetic neuropathy. J. Urol. (Baltimore) 76, 746-752 (1956).

2. Bischoff, A.: New morphologic and pathogenetic aspects of diabetic neuropathy, p. 627. Diabetes. Ed. J. Ostman. Excerpta med. Found. I.C.S. 172. Amsterdam: 1969 .

3. Bors, E., Comar, E.: Neurological disturbances of sexual function with special references to 529 patients with spinal cord injury. Urol. Surv. 10, 191-222 (1960).

4. Boyarsky, S.: Neurogenic bladder. Symposium. Ed. Wilkins-Wilkins. Baltimore: 1967.

5. Campos, C.A., Diaz Colodrero, A.: Estudios sobre la vejiga diabética. Rev. Asoc. méd. argent. 61, 669-672 (1947).

6. Cibeira, J. B., Dominelli, J. C., Buzzi, A.: Estudios elinicos y electromiograficos en 110 pacientes tratados con un derivado de las benzodiazepinas. La Prensa méd, argent. 51, 1544-1572 (1964).

7. - Cursillo de electromiografia. Rev. Asoc. méd. argent. 80, 560-567 (1966).

8. Coers, C., Hildebrand, J.: Latent neuropathy in diabetic and alcoholism. Neurology (Minneap.) 15, 19-38 (1965).

9. Colby, A. O.: Neurologic disorders of diabetes mellitus. 14, 424-429 (1965).

10. - Neurologic disorders of diabetes mellitus. Diabetes 14, 516-525 (1965).

11. Eliasson, S.G.: Changes in nerve lipid metabolism in experimental diabetes, p. 620. Diabetes. Ed. J. Ostman. Excerpta med. Found. I.C.S. 172. Amsterdam: 1969 .

12. Ellenberg, M. : Diabetic nourogenic vesical disfunction. A.M.A. Arch. intern. Med. 117, 348-354 (1966).

13. - The incipient asyntomatic bladder. Diabetes 16, $331-335$ (1967).

14. - Present status of diabetic neuropathy, p. 615 . Diabetes. Ed. J. Ostman. Excerpta med. Found. I.C.S. 172. Amsterdam: 1969.

15. Faerman, I., Maler, M., Jadzinsky, M.N., Fox, D., Alvarez, E., Zilverbarg, J., Cibeira, J.B., Colinas, R. : Vejiga neurogénica en diabeticos. Rev. Soc. argent. Urol. 38, $16-28$ (1969).

16. Fagerberg, S.: Recent advances in diabetic neuropathy. On the nature and treatment of diabetes, $p$.
522. Ed. Leibel, B.S., Wrenshall, G.A. Excerpta med. Found. 84. Amsterdam: 1965.

17. - A study of the urinary bladder in diabetic males and controls, p. 646. Diabetes. Ed. J. Ostman. Excerpta. Med. Found. I.C.S. 172. Amsterdam: 1969.

18. Field, R.: Altered nerve metabolism in diabetes, p. 617. Diabetes. Ed. J. Ostman. Excerpta med. Found. I.C.S. 172. Amsterdam: 1969.

19. Gregersen, G.: Latency time, maximal amplitude and electromiography in diabetics patients. Acta med. scand. 183, 55-60 (1968).

20. - Vibratory perception, threshold and motor conduction in diabetics and non diabetics. Acta med. scand. $183,61-65(1968)$.

21. Guzman, J.M.: Vejiga neurogénica. Actas del VIII Congreso Argentino de Urologia, 541 - 604 (1964).

22. Jadzinsky, M.N., Faerman, I., Fox, D., Varela, J., Gonzalez Casco, J., Schvartzman, R.: Tratamiento hormonal de la impotencia sexual del hombre diabético. Día Médico $\mathbf{3 9}, 862$ - 863 (1969).

23. - _ - Lesiones nerviosas en diabetes. Día Médico $39,1027-1030$ (1969).

24. - - Lesiones nerviosas en diabetes. Día Médico $39,1685-1687$ (1969).

25. Knowles, H., Guest, G., Lampe, R., Kessler, M.: The course of juvenile diabetic treated with unmeasured diet. Diabetes 14, 239-273 (1965).

26. Larcan, A., Huriet, G., Vaillandet, M., Fauchier, J. P.: Les manifestations vesicales au course du diabete. La Presse Medicale 75, 273-276 (1965).

27. Larsson, Y., Sterky, C.: Long term prognosis in juvenile diabetes mellitus. Acta Paediat. (Uppsala) 51, Suppl. 130, 5-76 (1961).

28. Marble, A.: Therapy; criteria of control. Diabetes. Mellitus, Diagnosis and Treatment. Ed. Amer. D. Assoc. N. York 1, 69-71 (1964).

29. - Angiopathy in diabetes, an unsolved problem. Diabetes 16, $825-838$ (1967).

30. Martin, M. : Involvement of autonomic fibers in diabetic neuropathy. Lancet 6760, 560-565 (1963).

31. Mouren, P., Serratrice, G., Tatossian, A.: Les manifestations nerveux des diabetiques, o. 66. Grenoble: Masson et Cie 1966.

32. Pirart, J.: Diabetic neuropathy, a metabolism or a vascular disease. Diabetes 14, $1-9$ (1965).

33. - Coers, C.: Diabetic neuropathy, a critical appraisal. p. 633. J. Ostman. Excerpta med. Found. I.C.S. 172. Amsterdam: 1969.

34. Schoffling, K., Federlin, K., Ditschuneit, H., Pfeiffer, B.F.: Disorders of sexual function in male diabetics. Diabetes 12, 519-527 (1963).

35. - Hypogonadism in male subjets. On the nature and treatment of diabetes. p. 505. Ed. Leibel, B.S., Wrenshall, G.A. Excerpta med. Found. I.C.S. 84. Amsterdam: 1965.

36. Sprague, R.G.: Impotence in male diabetics. Diabetes 12, $559-560$ (1963).

37. Thomas, P.K., Lascelles, R.G.: The pathology of diabetic neuropathy. Quarterly. J. Med. 35, 489-509 (1966).

38. World Health Organitation (W.H.O.): Technical series report. Diabetes mellitus. 310, 13-15 (1965).

39. Woolrch, J.. Garda, R.: Retencion vesical y vejiga neurogénica en la mujer. Rev. Mex. Urol. 28, 183-190 (1968).

40. Yamagata, S., Yamauchi, Y.: Diabetic neuropathy and triopathy. p. 649. Ed. J. Ostman. Excerpta Med. Found. I.C.S. 172. Amsterdam: 1969.

Dr. I. Faerman

Aroz $2663,5^{\circ}$ piso

Buenos Aires, Argentina 